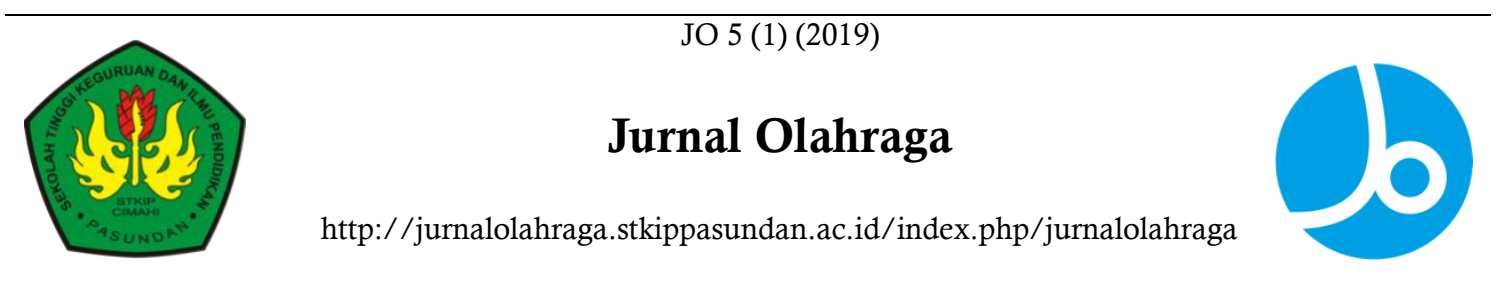

\title{
Peranan Olahraga Beladiri Militer Yongmoodo terhadap Kepercayaan Diri Anggota TNI-AD
}

\begin{abstract}
Sandi Dwi Triono
STKIP Pasundan, Indonesia

\begin{tabular}{l} 
Info Artikel \\
Sejarah Artikel: \\
Diterima Januari 2019 \\
Disetujui Maret 2019 \\
Dipublikasikan April 2019 \\
\hline Keywords: \\
Beladiri militer yongmoodo dan \\
Kepercayaan diri \\
\hline
\end{tabular}

Abstrak

Penelitian ini bertujuan untuk mengetahui apakah dampak beladiri militer Yongmoodo terhadap kepercayaan diri anggota TNI-AD. Metode yang digunakan yaitu metode ex post facto yang merupakan metode penelitian yang digunakan untuk memecahkan atau menjawab permasalahan yang dihadapi pada situasi sekarang. Populasi dalam penelitian ini yaitu anggota TNI-AD Secata-AD Pangalengan. Sampel yang digunakan berjumlah 27 orang yang dipilih melalui teknik simple random sampling. Instrumen yang digunakan yaitu berupa angket dengan jumlah soal yang digunakan 35 soal dengan reliabilitas instrument 0,893. Hasil dari uji taraf signifikansi menunjukan bahwa diketahui nilai Sig. (2-tailed) sebesar 0,000 lebih kecil dari < 0.05 yang berarti terdapat pengaruh yang signifikan olahraga beladiri yongmoodo terhadap kepercayaan diri anggota TNI-AD. Hasil dari pengolahan data presentase kepercayaan diri 91,78\%, dengan sub variabel keyakinan akan kemampuan diri sendiri 92,59\%, optimis $82,96 \%$, oobjektif 90,33\%, dan bertanggung jawab 91,85\%, rasional dan realistis 89,38\%. Kesimpulan dari penelitian ini yaitu terdapat pengaruh yang signifikan olahraga beladiri militer yongmoodo terhadap Kepercayaan diri anggota TNI-AD SECATA Pangalengan.
\end{abstract}

\begin{abstract}
This study aims to determine whether the impact of Yongmoodo military martial sports on the self-confidence of TNI-AD members. The method used is the ex post facto method which is a research method used to solve or answer the problems faced in the current situation. The population in this study were members of the Indonesian Armed Forces in the Army Pangalengan. The sample used amounted to 27 people selected through simple random sampling technique. The instrument used was in the form of a questionnaire with the number of questions used 35 questions with instrument reliability 0.893. The results of the test of significance level indicate that the value of Sig. (2-tailed) of 0,000 smaller than <0.05, which means that there is a significant influence of Yongmoodo martial arts
\end{abstract}


on the confidence of members of the Army. The results of processing the confidence percentage data were $91.78 \%$, with sub-variables of confidence in self-ability $92.59 \%$, optimistic $82.96 \%$, objective $90.33 \%$, and responsible $91.85 \%$, rational and realistic $89,38 \%$. The conclusion of this study is that there is a significant influence on the yongmoodo military martial arts against the confidence of members of the TNI-AD SECATA, Pangalengan.

(c) 2019 Sandi Dwi Triono Under the license CC BY-SA 4.0

Alamat korespondensi:

ISSN 2442-9961 (cetak)

E-mail: Sandidwitri@gmail.com

\section{PENDAHULUAN}

Bagi seorang militer, disamping harus memiliki keterampilan beladiri dan kebugaran jasmani yang baik, mereka harus juga memiliki mental yang sangat baik. Salah satu bentuk aspek mental yang harus dimiliki seorang militer adalah kepercayaan diri. Percaya diri adalah penilaian positif terhadap diri sendiri mengenai kemampuan yang ada dalam dirinya untuk menghadapi berbagai situasi dan tantangan serta kemampuan mental untuk mengurangi pengaruh negatif dari keragu-raguan yang mendorong individu untuk meraih keberhasilan atau kesuksesan tanpa tergantung kepada pihak lain dan bertanggung jawab atas keputusan yang telah ditetapkannya (Komarudin \& Hidayat, 2011). Seorang militer yang mempunyai percaya diri yang tinggi tidak akan ragu dalam mengambil berbagai keputusan, terlebih dalam menjaga integritas bangsa yang memang menjadi tugas pokoknya, karena pada dasarnya percaya diri merupakan suatu mekanisme penting yang mendasari suatu pencapaian individu (Lirgg, 2012).

Untuk menciptakan anggota militer yang berkualitas, baik itu secara jasmani, intelegitas, dan mental yang sempuna, setiap kesatuan militer memiliki tata cara tersendiri untuk melatihnya. Salah satunya melalui pelatihan olahraga beladiri.

Jenis olahraga beladiri yang diwajibkan oleh TNI selaku kesatuan militer yang ada di Indonesia adalah beladiri yongmoodo. Yongmoodo merupakan sejenis olahraga beladiri yang memadukan berbagai gerakan beladiri tradisional korea yaitu Taekwondo, Kumdo, Hapkido, Boxing, Judo, Ssirum dan Hon Sin Sul. Pada tahun 2008 yongmoodo resmi menjadi olahraga beladiri wajib di TNI Angkatan Darat, karena selain harus mempunyai kemampuan bertempur dengan sejata taktis angggota TNI-AD juga diwajibkan untuk menguasai beladiri militer yaitu yongmoodo.

Berdasarkan Peraturan Kasad nomor Perkasad/21-02/VI/2011 tanggal 8 Juni 2011 tentang yongmoodo menjadi Beladiri Militer, dimana yongmoodo masuk dalam kurikulum pendidikan Taruna Akademi Militer. Sehingga pelaksanaan kegiatan ujian kenaikan tingkat sabuk hitam (DAN I) bagi Taruna tingkat IV ini merupakan prasyarat kelulusan menjadi seorang Perwira. Setiap kesatuan memiliki standar pendidikan khusus, diantaranya yakni anak didiknya sebelum lulus diharapkan tidak hanya mempunyai kemampuan di bidang ilmu pengetahuan yang baik, namun juga harus mempunyai tingkat kebugaran respirasi yang baik untuk mundukung kinerja yang maksimal.

Melalui aktivitas tersebut selain meningkatkan keterampilan beladiri dan kebugaran jasmani (Barte \& Wendel-Vos, 2015; Sang-kyun, Jung-min, Ki-soo, Myungsun, \& Tae-bok, 2018; Sung-bae, 2018), diharapkan juga mampu meningkatkan kepercayaan diri anggota militer. Karena melalui berbagai jenis aktivita olahraga yang 
dirancang dan diprogram sedemikian rupa, rasa kepercayaan diri seseorang mampu meningkat (Hershow et al., 2015; Machida et al., 2016; Williams \& Cumming, 2015)

Berdasarkan hal tersebut, penulis tertarik untuk meneliti sejauh mana dampak yang diberikan oleh olahraga beladiri yongmoodo terhadap tingkat kepercayaan diri anggota militer.

\section{METODE}

Metode penelitian yang digunakan dalam penelitian ini adalah metode deskriptif ex post facto. Metode penelitian deskriptif ini digunakan untuk berupaya memecahkan atau menjawab permasalahan yang sedang dihadapi pada situasi sekarang . Dilakukan dengan langkah-langkah pengumpulan klarifikasi dan analisis/Pengolahan data serta membuat kesimpulan penggambaran tentang suatu keadaan secara objektif dalam suatu deskripsi situasi (Sugiyono, 2009).

Sementara itu populasi yang digunakan adalah anggota TNI AD Pusdik SECATA Rindam 3/Siliwangi Pangalengan yang berjumlah 120 orang, yang kemudian terpilih 27 orang sebagai sampel setelah melalui teknik simple random sampling. Penelitian ini diawali dengan studi pendahuluan. adapun penelitian dilaksanakan selama 3 pekan disesuaikan dengan jadwal latihan beladiri militer yongmoodo, Penulis mengambil di lokasi ini dikarenakan sarana dan prasarananya memadai untuk melakukan penelitian, Sehingga memudahkan dalam mencari data, peluang waktu yang luas dan subjek peneliti yang sangat di butuhkan oleh penulis.

Instrumen yang digunakan untuk memperoleh data dalam penilitian ini adalah angket. Angket tersebut merupakan pengembangan dari teori yang dikemukakan oleh Ghufron \& Risnawati (2010). Perolehan data tersebut kemudian diolah melalui uji-t menggunakan aplikasi SPSS versi 22.

\section{HASIL DAN PEMBAHASAN}

Setelah data diperoleh, kemudian penulis mengolah data tersebut dan pendistribusian hasilnya dapat dilihat pada tabel 1 di bawah ini :

\section{Tabel 1}

\section{Data hasil penelitian}

\begin{tabular}{|c|c|c|c|c|}
\hline Variabel & $\begin{array}{c}\text { Jumlah } \\
\text { Pernyataan }\end{array}$ & $\begin{array}{c}\text { Skor } \\
\text { Makimal }\end{array}$ & Skor & Aktual \\
\hline $\begin{array}{c}\text { Kepercayaan } \\
\text { Diri }\end{array}$ & 35 & 4,725 & 4,337 & 91,78 \\
\hline
\end{tabular}

Berdasarkan tabel di atas, dapat terlihat kepercayaan diri anggota TNI memiliki skor sebesar 4,337 atau 91,78\% dari nilai aktual (jumlah skor maksimal).

Selanjutnya dalam pengujian persyaratan analisis peneliti menggunakan uji normalitas dengan Shapiro-Wilk. Peneliti perlu menciptakan seluruh data berdistribusi normal, pengujian normalitas hasilnya dapat dilihat pada tabel 2 .

\section{Tabel 2}

\section{Hasil Data Perhitungan Uji Normalitas}

\begin{tabular}{|l|r|r|r|}
\hline \multicolumn{4}{|c|}{ Tests of Normality } \\
\hline & \multicolumn{3}{|c|}{ Shapiro-Wilk } \\
\cline { 2 - 4 } & Statistic & df & \multicolumn{1}{c|}{ Sig. } \\
\hline $\begin{array}{l}\text { Kepercayaa } \\
\text { n diri }\end{array}$ & .940 & 27 & .121 \\
\hline \multicolumn{2}{|l|}{ a. Lilliefors Significance Correction } \\
\hline
\end{tabular}

Berdasarkan hasil uji normalitas pada

Program IBM SPSS Statistic version 22 diketahui nilai signifikan sebesar $0.121>$ 0.05 maka dapat disimpilkan bahwa nilai berdistribusi normal.

Setelah pengujian normalitas, selanjutnya yaitu melakukan pengujian hipotesis. Pada pengujian hipotesis peneliti mengunakan Uji T-test, pengujian hipotesis dilakukan untuk mengetahui pengaruh tidaknya variabel yang diujikan kepada sampel peneliti. Dengan demikian adapun hasil pengujian hipotesis uji $t$ test diperlihatkan dalam tabel 3 di bawah ini: 
Tabel 3

Tabel Pengujian Hipotesis Uji T Test

\begin{tabular}{|c|c|c|c|c|c|c|}
\hline \multicolumn{7}{|c|}{ One-Sample Test } \\
\hline & \multicolumn{6}{|c|}{ Test Value $=4.59$} \\
\hline & \multirow[b]{2}{*}{$\mathrm{T}$} & \multirow[b]{2}{*}{$\mathrm{df}$} & \multirow{2}{*}{$\begin{array}{l}\text { Sig. } \\
(2- \\
\text { tailed })\end{array}$} & \multirow{2}{*}{$\begin{array}{c}\text { Mean } \\
\text { Difference }\end{array}$} & \multicolumn{2}{|c|}{$\begin{array}{c}95 \% \\
\text { Confidence } \\
\text { Interval of the } \\
\text { Difference }\end{array}$} \\
\hline & & & & & Lower & Upper \\
\hline $\begin{array}{l}\text { Kepercyaa } \\
\text { n Diri }\end{array}$ & $\begin{array}{r}112 . \\
095\end{array}$ & 26 & .000 & 156.040 & $\begin{array}{r}153.1 \\
8\end{array}$ & $\begin{array}{r}158.9 \\
0\end{array}$ \\
\hline
\end{tabular}

Berdasarkan tabel di atas diketahui

bahwa nilai Sig. (2-tailed) sebesar 0,000 lebih kecil dari 0.05 maka dapat disimpulkan $\mathrm{H}_{1}$ diterima dan $\mathrm{H}_{\mathrm{o}}$ ditolak. Artinya terdapat pengaruh yang signifikan beladiri militer yongmoodo terhadap kepercayaan diri.

Hasil uji t test membuktikan bahwa beladiri militer yongmoodo berpengaruh terhadap kepercayaan diri anggota TNI. Maka penulis menyempurnakan data dengan presentase yang menunjukan bahwa rata-rata skor kepercayaan diri angggota TNI-AD 4.59 atau $70 \%$. Berdasarakan kriteria jawaban yang dibuat oleh sugiyono (2009), maka kepercayaan diri skor dibawah $20 \%$ (sangat rendah), skor $20 \%$ sampai $40 \%$ (rendah), skor $41 \%$ sampai $60 \%$ (cukup tinggi), skor $61 \%$ sampai $80 \%$ (tinggi) dan $81 \%$ sampai $100 \%$ (sangat tinggi). Kategori kepercayaan diri anggota TNI termasuk kedalam kategori tinggi.

Tabel 4. Daftar distribusi frekuensi Kepercayaan diri

\begin{tabular}{|c|c|c|c|c|}
\hline No. & $\begin{array}{c}\text { Kelas } \\
\text { interval }\end{array}$ & Frekuensi & Relatif \% & Kriteria \\
\hline 1 & $140-146$ & 1 & $3,70 \%$ & $\begin{array}{c}\text { Sangat } \\
\text { Rendah }\end{array}$ \\
\hline 2 & $147-153$ & 4 & $14,81 \%$ & Rendah \\
\hline 3 & $154-160$ & 4 & $14,81 \%$ & $\begin{array}{c}\text { Cukup } \\
\text { Tinggi }\end{array}$ \\
\hline 4 & $161-167$ & 13 & $48,15 \%$ & Tinggi \\
\hline 5 & $168-174$ & 5 & $18,52 \%$ & $\begin{array}{c}\text { Sangat } \\
\text { Tinggi }\end{array}$ \\
\hline Jumlah & & 27 & $100 \%$ & \\
\hline
\end{tabular}

Berdasakan hal di atas dapat dijelaskan bahwa hasil penelitian tentang kepercayaan diri diperoleh nilai terendah 140 dan yang tertinggi 172. Anggota TNI yang memperoleh skor $140-146$ sejumlah 1 orang $(3,70 \%)$ dalam kriteria sangat rendah, anggota yang memperoleh skor 147-153 sejumlah 4 orang $(14,81 \%)$ dalam kriteria rendah, anggota yang memperoleh skor 154-160 sejumlah 4 orang $(14,81 \%)$ dalam kriteria cukup tinggi, anggota yang memperoleh skor 161-167 sejumlah 13 orang $(48,15 \%)$ dalam kriteria tinggi, dan anggota yang memperoleh skor 168-174 sejumlah 5 orang (18,52\%). Jadi dapat disimpulkan bahwa kepercayaan diri anggota TNI-AD dengan sampel 27 dominan anggota TNI-AD termasuk dalam kriteria tinggi dalam kepercayaan diri.

Tabel 5. Hasil presentase sub variabel dan hasil penelitian

\begin{tabular}{|c|c|c|c|c|}
\hline Sub variabel & $\begin{array}{c}\text { Banyaknya } \\
\text { pertanyaan }\end{array}$ & Akor & $\begin{array}{c}\text { Skor } \\
\text { ideal }\end{array}$ & $\%$ \\
\hline $\begin{array}{c}\text { Keyakinan } \\
\text { akan } \\
\text { kemampuan } \\
\text { diri }\end{array}$ & 7 & 1375 & 1485 & 92,59 \\
\hline Optimis & 7 & 1232 & 1485 & 82,96 \\
\hline Objektif & 7 & 845 & 945 & 90,33 \\
\hline $\begin{array}{c}\text { Bertanggung } \\
\text { jawab }\end{array}$ & 8 & 992 & 1080 & 91,85 \\
\hline $\begin{array}{c}\text { Rasional dan } \\
\text { realistis }\end{array}$ & 6 & 724 & 810 & 89,38 \\
\hline
\end{tabular}

Berdasarkan hasil tabel 5 di atas, sub variabel keyakinan akan kemampuan diri memilik skor 1375 atau 92,59\% dari skor ideal, sub variabel optimis memiliki skor 1232 atau 82,96 \% dari skor ideal, sub variabel objektif memiliki skor 845 atau $90,33 \%$ dari skor ideal, dan sub variabel bertanggung jawab memiliki skor 992 atau $91,85 \%$ dari skor ideal, sub variabel rasional dan realistis memiliki skor 724 atau 89,38 dari skor ideal. Berdasarkan data tabel tersebut, kepercayaan diri anggota TNI AD dominan pada keyakinan akan kemampuan diri.

Tabel 6. Hasil presentase sub variabel

keyakinan akan kemampuan diri

\begin{tabular}{|c|c|c|c|c|c|}
\hline Indikator & $\begin{array}{c}\text { Banyaknya } \\
\text { pertanyaan }\end{array}$ & $\begin{array}{c}\text { No } \\
\text { soal }\end{array}$ & $\begin{array}{c}\text { Skor } \\
\text { ideal }\end{array}$ & $\begin{array}{c}\text { Skor } \\
\text { actual }\end{array}$ & $\%$ \\
\hline
\end{tabular}




\begin{tabular}{|c|c|c|c|c|c|}
\hline $\begin{array}{c}\text { Ketika } \\
\text { menghadapi } \\
\text { tantangan }\end{array}$ & 4 & $\begin{array}{c}1,2, \\
5,6\end{array}$ & 540 & 490 & 90,74 \\
\hline $\begin{array}{c}\text { Dalam } \\
\text { menghadapi } \\
\text { kehidupan }\end{array}$ & 3 & $\begin{array}{c}3,4, \\
7\end{array}$ & 405 & 384 & 94,81 \\
\hline
\end{tabular}
variabel keyakinan akan kemampuan diri di atas terlihat bahwa indikator ketika menghadapi tantangan memiliki skor 490 atau 90,74 \% dari skor ideal, dalam menghadapi kehidupan memiliki skor 384 atau 94,81 \% dari skor ideal, Dari sub variabel keyakinan akan kemampuan diri indikator dalam menghadapi kehidupan lebih dominan dari indikator ketika menghadapi tantangan.

Tabel 7. Hasil presentase sub variabel optimis

\begin{tabular}{|c|c|c|c|c|c|}
\hline Indikator & $\begin{array}{c}\text { Banyaknya } \\
\text { pertanyaan }\end{array}$ & No soal & $\begin{array}{c}\text { Skor } \\
\text { ideal }\end{array}$ & $\begin{array}{c}\text { Skor } \\
\text { aktual }\end{array}$ & $\%$ \\
\hline $\begin{array}{c}\text { Optimis } \\
\text { dalam } \\
\text { kehidupan } \\
\text { sehari-hari }\end{array}$ & 3 & $8,9,12$ & 405 & 378 & $\begin{array}{c}93,33 \\
\%\end{array}$ \\
\hline $\begin{array}{c}\text { Optimis } \\
\text { dalam } \\
\text { menjalankan } \\
\text { tugas }\end{array}$ & 4 & $10,11,13,14$ & 540 & 495 & $\begin{array}{c}91,66 \\
\%\end{array}$ \\
\hline
\end{tabular}

Berdasarkan tabel hasil presentase sub variabel optimis di atas terlihat bahwa indikator optimis dalam kehidupan seharihari memiliki skor sejumlah 378 atau 93,33 $\%$ dari skor ideal, optimis dalam menjalankan tugas memiliki skor sejumlah 495 atau 91,66 $\%$ dari skor ideal. Dari tabel sub variabel optimis indikator optimis dalam kehidupan sehari-hari lebih dominan dari indikator optimis dalam menjalankan tugas.

Tabel 8. Hasil presentase sub variabel

\begin{tabular}{|c|c|c|c|c|c|}
\hline Indikator & $\begin{array}{c}\text { Banyaknya } \\
\text { pernyataan }\end{array}$ & No soal & $\begin{array}{c}\text { Skor } \\
\text { ideal }\end{array}$ & $\begin{array}{c}\text { Skor } \\
\text { aktual }\end{array}$ & $\%$ \\
\hline $\begin{array}{c}\text { Mampu } \\
\text { menilai } \\
\text { diri sendiri }\end{array}$ & 3 & $15,18,19$ & 405 & 359 & $\begin{array}{c}87,90 \\
\%\end{array}$ \\
\hline $\begin{array}{c}\text { Mampu } \\
\text { menilai } \\
\text { orang lain }\end{array}$ & 4 & $16,17,20,21$ & 540 & 369 & $\begin{array}{c}91,11 \\
\%\end{array}$ \\
\hline
\end{tabular}

Berdasarkan tabel hasil presentase sub variabel objektif di atas terlihat bahwa indikator mampu menilai sendiri memiliki skor sejumlah 359 atau 93,33\% dari skor ideal, mampu menilai orang lain memiliki skor sejumlah 369 atau $91,11 \%$ dari skor ideal. Dari tabel sub variabel objektif indikator mampu menilai orang lain lebih dominan dari indikator mampu menilai diri sendiri.

Tabel 9. Hasil presentase sub variabel bertanggung jawab

\begin{tabular}{|c|c|c|c|c|c|}
\hline Indikator & $\begin{array}{c}\text { Banyaknya } \\
\text { pertanyaan }\end{array}$ & No soal & $\begin{array}{c}\text { Skor } \\
\text { ideal }\end{array}$ & $\begin{array}{c}\text { Skor } \\
\text { aktual }\end{array}$ & $\%$ \\
\hline $\begin{array}{c}\text { Bertanggun } \\
\text { g jawab } \\
\text { pada diri } \\
\text { sendiri }\end{array}$ & 4 & $\begin{array}{c}22,23,26, \\
27\end{array}$ & 540 & 510 & $\begin{array}{c}94,44 \\
\%\end{array}$ \\
\hline $\begin{array}{c}\text { Bertanggun } \\
\text { g jawab } \\
\text { pada tugas } \\
\text { yang sudah } \\
\text { diberikan }\end{array}$ & 4 & $\begin{array}{c}24,25,28, \\
29\end{array}$ & 540 & 482 & $\begin{array}{c}89,25 \\
\%\end{array}$ \\
\hline
\end{tabular}

Berdasarkan hasil tabel presentase sub variabel bertanggung jawab di atas, indikator bertanggung jawab pada diri sendiri memiliki sekor sejumlah 510 atau 94,44\% dari skor ideal dan indikator bertanggung jawab pada tugas yang sudah diberikan memiliki sekor sejumlah 482 atau 89,25\% dari sekor ideal. Pada sub variabel bertanggung jawab di atas, menunjukan bahwa indikator bertanggung jawab pada diri sendiri lebih dominan dari pada indikator bertanggung jawab pada tugas yang sudah diberikan .

Tabel 10. Hasil presentase sub variabel

\section{Rasional dan realistis}

\begin{tabular}{|c|c|c|c|c|c|}
\hline Indikator & $\begin{array}{c}\text { Banyaknya } \\
\text { pertanyaan }\end{array}$ & No soal & $\begin{array}{c}\text { Skor } \\
\text { ideal }\end{array}$ & $\begin{array}{c}\text { Skor } \\
\text { actual }\end{array}$ & $\%$ \\
\hline $\begin{array}{c}\text { Rasional dan } \\
\text { realistis ketika } \\
\text { menghadapi } \\
\text { permasalahan }\end{array}$ & 3 & $30,32,33$ & 405 & 373 & $\begin{array}{c}92,09 \\
\%\end{array}$ \\
\hline $\begin{array}{c}\text { Rasional dan } \\
\text { realistis dalam } \\
\text { bertindak }\end{array}$ & 3 & $31,34,35$ & 405 & 369 & $\begin{array}{c}91,11 \\
\%\end{array}$ \\
\hline \multicolumn{3}{|c|}{ Berdasarkan data tabel hasil } \\
\hline
\end{tabular}

presentase sub variabel rasional dan realistis di atas, indikator rasionaldan realistis ketika menghadapi permasalahan memiliki skor 373 atau $92,09 \%$ dari skor ideal, dan indikator rasional dan realistis dalam bertindak 
memiliki skor 369 atau 91,11\% dari skor ideal. Dapat disimpulkan bahwa indikator rasional dan realistis ketika menghadapi permasalahan yang mencapai dominan dari pada indikator rasional dan realistis dalam bertindak.

Tabel 11

Data hasil perhitungan dari penyebaran angket kepercayaan diri anggota TNI-AD

\begin{tabular}{|c|c|c|c|c|c|}
\hline Variabel & $\mathbf{N}$ & $\mathbf{X}$ & $\mathbf{S}$ & S2 & Jumlah \\
\hline $\mathrm{X}$ & 27 & 160,62 & 8,32 & 69,22 & 4337 \\
\hline
\end{tabular}

Dari tabel di atas, diketahui nilai ratarata dari angket kepercayaan diri adalah 160,62 dari simpangan baku sebesar 8,32.

Tabel 12.

Data hasil keseluruhan indikator

\begin{tabular}{|c|c|c|}
\hline No. & Indikator & $\begin{array}{c}\text { Skor } \\
\text { Presentase } \\
\%\end{array}$ \\
\hline 1 & Ketika menghadapi tantangan & $90.74 \%$ \\
\hline 2 & $\begin{array}{c}\text { Dalam menghadapi } \\
\text { kehidupan }\end{array}$ & $94.81 \%$ \\
\hline 3 & $\begin{array}{c}\text { Optimis dalam kehidupan } \\
\text { sehari-hari }\end{array}$ & $92.77 \%$ \\
\hline 4 & $\begin{array}{c}\text { Optimis dalam menjalankan } \\
\text { tugas }\end{array}$ & $93.30 \%$ \\
\hline 5 & Mampu menilai diri sendiri & $91.66 \%$ \\
\hline 6 & Mampu menilai orang lain & $87.90 \%$ \\
\hline 7 & $\begin{array}{c}\text { Bertanggung jawab pada diri } \\
\text { sendiri }\end{array}$ & $94.44 \%$ \\
\hline 8 & $\begin{array}{c}\text { Bertanggung jawab pada } \\
\text { tugas yang di berikan }\end{array}$ & $89.25 \%$ \\
\hline 9 & $\begin{array}{c}\text { Rasional dan realistis ketrika } \\
\text { menghadapi permasalahan }\end{array}$ & $92.09 \%$ \\
\hline 10 & $\begin{array}{c}\text { Rasional dan realistis dalam } \\
\text { bertindak }\end{array}$ & $91.11 \%$ \\
\hline
\end{tabular}

Hasil dari pengolahan analisis data didapatkan presentase kepercayaan diri sebesar $91,78 \%$ dengan rincian sub variabel keyakinan akan diri sendiri $92,59 \%$, optimis $82,96 \%$, objektif $90,33 \%$, bertanggung jawab 91,85\% dan sub variabel rasional dan realistis $89,38 \%$. Pada saat penelitian, peneliti menemukan beberapa temuan yang menjadi bahan untuk diskusi sebagai berikut: Kepercayaan diri merupakan suatu salah satu aspek kepribadian yang penting pada seseorang guna mencapai tujuannya
(Hershow et al., 2015), dalam hal itu kepercayaan diri merupakan bagian dari aspek afektif. Dalam sikap seseorang pada suatu hal, terutama pada rasa kepercayaan diri, terdapat dari berbagai respon dari setiap individu. Menanggapi hal tersebut, kepercayaan diri dapat timbul dari individu itu sendiri atau dipengaruhi oleh faktor dari dalam maupun faktor dari luar. Tentunya dengan adanya rasa kepercayaan diri pada seseorang dapat menjalankan kehidupannya dengan baik.

Untuk menimbulkan rasa kepercayaan diri pada anggota TNI-AD, tentunya banyak faktor yang mempengaruhinya,selain keyakinan akan kemampuan dirinya sendiri peran dari pelatih dalam hal ini yaitu untuk meningkatkan rasa kepercayaan diri anggota TNI-AD yang mengikuti proses Pendidikan SECATA, agar selama proses pendidikan dapat berlangsung dengan baik dan tujuan yang diharapkan dari hasil belajar tercapai.

Olahraga beladiri yongmoodo selain dapat meningkatkan berbagai kemampuan fisik seseorang (Debbian \& Rismayanthi, 2016; Min-cheol, Tae-bok, \& Jung-min, 2017), dalam penelitian ini juga membuktikan adanya dampak positif lain yaitu melalui aktivitas pelatihan beladiri yongmoodo, kepercayaan diri anggota TNIAD dapat meningkat. Hal tersebut berbanding lurus dengan penelitian-penelitian terdahulu yang membuktikan adanya dampak positif aktivitas olahraga terhadap peningkatan kepercayaan diri seseorang (Hershow et al., 2015; Machida et al., 2016).

\section{KESIMPULAN}

Berdasarkan hasil penelitian ini, dapat disimpulkan bahwa beladiri militer yongmoodo menimbulkan kepercayaan diri yang signifikan dari anggota TNI-AD hal ini dikarenakan dilihat dari hasil perhitungan presentase kepercayaan diri sebesar 91,78\% dengan rincian sub variabel keyakinan akan diri sendiri $92,59 \%$, optimis 82,96\%, 
objektif 90,33\% , bertanggung jawab 91,85 $\%$ dan sub variabel rasional dan realistis $89,38 \%$. Hal tersebut mengemukakan bahwa pelatihan olahraga beladiri militer yongmoodo memang sangat baik dan cocok untuk diterapkan sebagai olahraga beladiri wajib militer, karena selain mampu meningkatkan kemampuan beladiri anggotanya, aspek lain seperti kemampuan fisik, kebugaran jasmani, serta mampu meningkatkan beberapa aspek mental yang memang harus dimiliki oleh seorang anggota militer, salah satunya kepercayaan diri,

Penulis menyadari bahwa banyaknya kekurangan selama penelitian dilakukan dan masih banyak hal lain yang kiranya perlu diadakan penelitian lebih lanjut untuk mendalami dan meneliti dampak-dampak positif lainnya yang dapat ditingkatkan melalui aktivitas beladiri yongmoodo.

\section{DAFTAR PUSTAKA}

Barte, J. C. M., \& Wendel-Vos, G. C. W. (2015). A Systematic Review of Financial Incentives for Physical Activity: The Effects on Physical Activity and Related Outcomes. Behavioral Medicine, 4289(October). https://doi.org/10.1080/08964289.2015. 1074880

Debbian, A., \& Rismayanthi, C. (2016). Profil Tingkat Volume Oksigen Maskimal (Vo2 Max) dan Kadar Hemoglobin (Hb) pada Atlet Yongmoodo Akademi Militer Magelang. Jurnal Olahraga Prestasi, 12, 19-30.

Ghufron, Nur \& Risnawati, Rini. (2010). Teori-Teori Psikologi. Yogyakarta : Arruz Media.

Hershow, R. B., Gannett, K., Merrill, J., Kaufman, B., Barkley, C., Decelles, J., ... Harrison, A. (2015). Using Soccer to Build Confidence and Increase HCT Uptake Among Adolescent Girls: A Mixed-Methods Study of an HIV Prevention Programme in South Africa. Sport in Society, 0437(September). https://doi.org/10.1080/17430437.2014. 997586

Komarudin \& Hidayat .(2013). Psikologi Olahraga .Bandung : Rosda.

Lirgg, C. D. (2012). Girls and Women, Sport , and Self-Confidence. Quest, (April 2015), 158-178. https://doi.org/10.1080/00336297.1992. 10484049

Machida, M., Otten, M., Magyar, T. M., Vealey, R. S., Marie, R., Machida, M., ... Vealey, R. S. (2016). Examining Multidimensional Sport-Confidence in Athletes and Non-Athlete Sport Performers. Journal of Sports Sciences, 0414(April).

https://doi.org/10.1080/02640414.2016. 1167934

Min-cheol, K., Tae-bok, K., \& Jung-min, P. (2017). Effects of YONGMOODO Exercises on Physical Fitness and Gait Ability in Body Imbalance Obesity Elementary Students. International Journal of Martial Arts, 2(2), 1-9.

Sang-kyun, P., Jung-min, P., Ki-soo, L., Myung-sun, L., \& Tae-bok, K. (2018). Effects of Naegong-Chesool EXERCISE on Physical Fitness and Balance Abilities in Male Elderly. International Journal of Sport, 3(2), 26-33.

Sugiyono. (2009). Metode Penelitian kuantitatif, kualitatif, dan $R \& D$. Bandung : Alfabeta.

Sung-bae, P. (2018). Improving First Aid Education through Analysis of First Aid by MARTIAL ART field. International Journal of Martial Arts, 3(1), 14-19.

Williams, S. E., \& Cumming, J. (2015). Athlete Imagery Ability: A Predictor of Confidence and Anxiety Intensity and Direction. International Journal of Sport and Exercis Psychology, (May), $37-41$. https://doi.org/10.1080/1612197X.201 5.1025809 